\title{
Duygusuzlaş(tır)madan Korumanın Yol Haritası: Koruyucu Psikoloji \\ Çocuk Eğitiminde Duygusal Rehberlik
}

INCELEYEN: HILAL KAZICI

"Mükemmel değil, merhametli çocuklar yetiştirmeyi hedefleyin."

İnsan iç dünyasında envâi çeşit duyguyu bir arada barındırır. Hayatın manâsını kavrayabilen ve kendisiyle barışık bireyler yetiştirmenin yolu bu duyguları layıkıyla tanımaktan geçer (Cüceloğlu, 2008, s. 195-209). Duygulardan çok duyulara önem verilen modern çağda, insanın iç dünyasında barındırdığı duyguları layıkıyla tanımak ise oldukça meşakkatli bir hâl almıştır. Çağımıza özgü önemli bir sorun olan bu durum iki profesyonel ruh bilimcimizin gözünden kaçmamıştır.

Prof. Dr. Kemal Sayar ile Uzman Psikolog Feyza Bağlam'ın birlikte kaleme aldığı Koruyucu Psikoloji adlı eserin ilk baskısı 2010 yılında, son

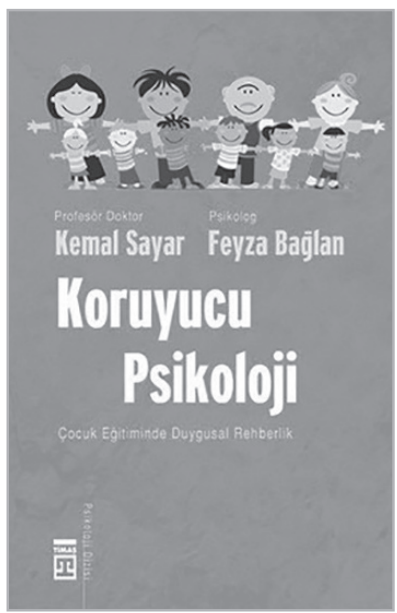
baskısı ise 2015 yılında Timaş Yayınları'ndan çıkmıştır. Çocukların eğitiminde duygusal rehberliğin önemine dikkat çekmek amacıyla kaleme alınan eser on bir bölümden oluşmaktadır. Sunuş yazısında

- KITAP INCELEMESi-

HILAL KAZICI, hilalkazici@hotmail.com Rehber Ögrretmen 
eserin temel sorusu şu şekilde ifade edilmiştir: "vicdan ve merhamet sahibi, ahlaki ve duygusal zekâları yüksek, dayanışma duygusuna sahip mütevazi ve diğerkâm çocuklar yetiştirmek için ne yapabiliriz?" (Sayar, Bağlan, 2015, s. 18). Bu sorunun yanı sıra çocukları dış dünyanın saldırılarından ve getirebileceği gerginlikten nasıl korunabileceği de tartışılmıştır. Günümüzde çocuk yetiştirmenin giderek zorlaştığını ifade eden yazarlarımız, geleneksel ebeveynlik anlayışı ile günümüz ebeveynlik anlayışı arasındaki farklılığa dikkat çekmişlerdir. Geçmişte iyi anne babalık denildiğinde çocukları beslemek, duygusal ve sosyal açıdan gelişmelerine yardım etmek anlaşılırken günümüzde iyi anne babalık, bunların yanı sıra çocukların ne yaptığını yakından gözlemek anlamına gelmektedir. Yazarlarımıza göre bu durum kuşkucu ebeveynliğin giderek yaygınlaştığını göstermektedir. Yirmi dört saat boyunca çocuklarını gözlemlemek isteyen, güvenlik konusunda adeta saplantılı bir korkuya sahip bu ebeveynlik tutumunun ortaya çımasına neden olan en önemli etken ise çocukların kolayca incinebilen ve zayıf varlıklar olduğu düşüncesidir. Psikolojide hâkim görüş olan bu düşüncenin zihinlerde kalıplaşmasından doğabilecek sorunları dile getiren yazarlarımız aslında çocukların zorluklar karşısında bir hayli güçlü mukavemete sahip olduklarını vurgulamışlardır (Sayar, Bağlan, 2015, s. 15-16). Samimi bir üslupla kaleme aldıkları giriş yazısında, ebeveynleri, çocuklarının bu güçlü yönünü tanımaya davet etmişlerdir.

İnsanın karanlık yönünü kurcalayan klasik psikoloji çalışmalarının sınırlarını aşarak, insanın güçlü yönünü gün yüzüne çıartmayı amaçlayan yazarlarımız, eserin ilk bölümünde gelişim dönemlerini farklı bir bakış açısıyla ele almaya çalışmışlardır. İlk olarak, ruhsal hastalığı olan kişilerle aynı süreçleri geçirdiği hâlde bir patolojisi olmayan insanları hangi unsurların koruduğunu araştırmaya koyulmuşlardır. Çok sayıda araştırma raporunu analiz ederek, ulaştıkları bilgiler doğrultusunda kişilik gelişimini etkileyen risk faktörlerini ve koruyucu faktörleri; bireysel ve toplumsal boyutlarıyla objektif bir bakış açısıyla değerlendirmişlerdir. İnsanın ruhsal gelişimini etkileyen koruyucu faktörlerin en az risk faktörleri kadar fazla olduğunu tespit eden yazarlarımız konuyla ilgili tezlerini şu şekilde ifade etmişlerdir: "Maruz kaldığımız ve hayatımızda mutlaka etkisinin olduğunu ön gördüğümüz olumsuz olaylar var olsa bile, elimizde onların etkilerini en aza indirebilecek imkânlar da mevcuttur. Bunların başında Sevgiye Dayalı, Hoşgörülü, Destekleyici ve Sınırları Belli bir aileye sahip olmak gelmektedir." (Sayar, Bağlan, 2015, s. 27).

Eserin devamında ise aile konusunu daha detaylı biçimde ele almışlardır. Aile içindeki ilişki biçimlerini evlilik ilişkisi, ebeveyn - çocuk ilişkisi ve kardeşler arasındaki ilişkiler olmak üzere üç boyutta açıklamışlardır. Kendi içlerinde bağımsız ama birbiriyle bağlantılı olan bu ilişki döngüsünün, sağlıklı bir şekilde işlevini sürdürebilmesi için ailede sınırların net olarak belirlenmesi gerektiğini vurgulamışlardır. Aynı zamanda bu sınırların; tutarlı, sevgiyle belirlenmiş ve 
aile fertlerinin bireysel varlıklarına saygı duyar nitelikte olması gerektiğinin de altını çizmişlerdir. Yazarlarımız ideal aile yapısının özelliklerini tasvir ederken bir taraftan da problemli aile yapılarının özelliklerini açıklamışlardır. Bu noktada problemin iki zıt ucunu temsil eden, katı sınırlı aile ve muğlak sinırlı aile yapılarını mercek altına almışlardır. Sınırların katı ve aşılmaz olduğu ailede bireylerin duygusal destek alıp-verme konusunda zorluklar yaşayabileceği ve hatta aidiyet hissinin eksilebileceğini belirtmişlerdir. Sınırları muğlak olan aile yapısında ise hastalıklı bir "biz bütünüz/sen, ben fark etmez" anlayışının hâkim olduğuna dikkat çeken yazarlarımız, bu tür aile yapılarında ise bireylerin kişisel karar verme yetisinden mahrum kalabileceğini ifade etmişlerdir. Ayrıca eserin bu bölümünde problemli ebeveyn - çocuk ilişkilerini, çeşitli alt başlıklar kullanarak tanımlamışlardır (Sayar, Bağlan, 2015, s. 43-48).

Eserin ilk dört bölümünde duygusal rehberlik eğitimine dair merak uyandıran yazarlarımız, beşinci bölümde, duygusal rehberlik konusunu incelemişler ve eserin anahtar kavramı olan "duygusal zekâ" yı şu şekilde tanımlamışlardır: "İnsanın kendi duygularını ve karşısındaki insanın duygularını anlaması ve anlamlandırması, hissedilen farklı duyguları ayrıştırarak analiz edebilmesidir.” (Sayar, Bağlan, 2015, s. 81). Ebeveynlerin duygusal rehberlik yapabilmesi, çocukların duygusal zekâsının gelişimine önemli ölçüde katkı sağlayacaktır. Yazarlarımız, ilk duyuşta kulağa yabancı gelen bu ifadeyi daha anlaşılır kılmak için, duygusal rehberlik konusunu çocuğun gelişim dönemlerine göre sınıflandırarak açıklamışlardır. Ayrıca ele alınan konuyla yakından ilişkili olan empati kavramını tanımlayarak, empati gelişimini sekteye uğratacak faktörleri sıralamışlardır. Her çocuğun empati kurabilme yeteneği ile doğduğunu, ancak bu yeteneğin aile tarafından desteklenmesi gerektiğini vurgulamışlardır. Böylesi bir desteğin ise ancak çocuğa karşı empati duymakla sağlanabileceğini, çeşitli örnekler vererek açıklamışlardır. Konunun bağlamından fazla uzaklaşmadan, duygusal rehberlik eğitimini beş aşamada anlatmışlardır. Birinci adım; çocuğun duygularının farkında olmak. Çocuğun duygularını keşfetmenin ancak ve ancak ebeveynlerin kendi duygularını tanımalarıyla mümkün olacağını vurgulayan yazarlarımız, bu aşamanın duygusal rehberliğin bel kemiğini oluşturduğunu vurgulamışlardır. İkinci adım; duyguları tanımayı samimiyet kurmak ve çocuğa bir şeyler sunabilmek için fırsata dönüştürmek. Bu aşamada, olumsuz hisleri henüz düşük seviyedeyken fark etmenin önemine değinilmiştir. Üçüncü adım; çocuğu empatik bir şekilde dinlemek ve duygularını değerli bulduğumuzu ifade etmek. Ebeveynlerin çocukları ile aynı frekansı yakalayabilmeleri için, çocuğun beden diline, jest ve mimiklerine dikkat etmeleri gerektiğini belirten yazarlarımız bu aşamada ebeveynlerin çocuklarını anladıklarını açıkça belli etmesi gerektiğini örnekler vererek açıklamışlardır. Dördüncü adım; çocuğun duygularını isimlendirmesine yardımcı olma. Yazarlarımıza göre bu adım duygusal rehberliğin en önemi aşamasıdır. Bu adımda anne-babalar çocuklarına korku, üzüntü, öfke gibi günlük hayatta karşılarına çıkabilecek duyguları 
öğretmelidirler. Beşinci adım; çocuğa problem çözerken, yardımcı olurken sınırları çizmek. Bu aşamadan ebeveynlerin birazcık zorlanabileceğini ifade eden yazarlarımız, çocuğa sorunlarla baş etme becerisinin kazandırılması gerektiğini belirtmişlerdir. Ayrıca istenmedik davranışlar sergileyen bir çocuğun duygularına değil, davranışlarına sınır koyulması gerektiğini vurgulamışlardır (Sayar, Bağlan, 2015, s. 83-108).

Bütün tespitlerini bilimsel verilerle temellendirerek açıklayan yazarlarımız eserin son altı bölümünü de büyük bir titizlikle kalem almışlardır. Annebaba anlaşmazlığı, boşanma, ailedeki riskler gibi önemli konuları etraflıca tartışmışlardır. Çocukların da krizi fırsata çevirme gücüne sahip varlıklar olduklarını önemle vurgulamışlardır. Ayrıca eserin son kısmına, anne-babaların kendi ebeveynlik tutumlarını tespit edebilecekleri, pratik bir test çalışması eklemişlerdir.

Yüreklerindeki heyecanı satır aralarına serpiştiren yazarlarımız; duygusal rehberlik konusuna ilgi duyan ebeveynlere, ihtiyaç duyabilecekleri her türlü imkânı sunmaya çalışmışlardır. Modern dünyanın tüm tehlikesine rağmen; adil, hoşgörülü, mutlu, zarif ve aynı zamanda cesur çocuklar yetiştirmenin ne kadar mühim ve mümkün olduğunu hatırlatmışlardır.

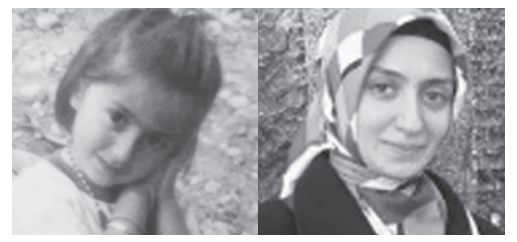

Hilal Kazıcı

\section{Kaynakça}

Cüceloḡlu, D. (2008). Korku Kültürü (7. B.). İstanbul: Remzi Kitapevi.

Sayar , K., \& Bağlan, F. (2015). Koruyucu Psikoloji (7. B.). İstanbul : Timaș Yayınları. 